\title{
The Reemergence and Management of Currant Cane Dieback in the Northeastern United States
}

\author{
Stacy D. Singer and Kerik D. Cox, Department of Plant Pathology and Plant-Microbe Biology, New York State Ag- \\ ricultural Experiment Station, Cornell University, Geneva, NY 14456
}

\begin{abstract}
Singer, S. D., and Cox, K. D. 2010. The reemergence and management of currant cane dieback in the northeastern United States. Plant Dis. 94:1283-1289.

Currant cane dieback, caused by the fungus Botryosphaeria ribis (syn. Neofusicoccum ribis), devastated currant production in the northeastern United States approximately a century ago. Later epidemics of this disease were halted by bans on the planting of Ribes spp. to control white pine blister rust, but since regulations restricting the planting of currants were removed in the 1980s and 1990s, currant cane dieback has reemerged in the northeastern United States. In this study, we obtained fungal isolates from diseased canes at four production operations in New York and Connecticut. We confirmed the isolates as N. ribis on the basis of morphology and ribosomal DNA sequence analysis, and verified pathogenicity through inoculation of healthy currant bushes. Furthermore, field trials to study the effects of cultivar, pruning of symptomatic canes, and fungicide applications were conducted over 2 years. Differences in Ribes cultivar susceptibility to $N$. ribis were demonstrated, with a pink fruiting cultivar (Pink Champagne) having lower levels of dieback compared to two red cultivars (Rovada and Jonkheer van Tets) and one white cultivar (Blanka) evaluated. While there were no consistent reductions in cane dieback incidence over both years and for all cultivars when pruning or fungicide treatments (copper hydroxide and sulfur applications) were used alone, fungicide treatment combined with pruning resulted in significant $(P<0.05)$ reductions $(>80 \%)$ in the incidence of dieback compared to bushes not treated with fungicide or pruned.
\end{abstract}

During the late nineteenth and early twentieth centuries, a dieback of currants (Ribes spp.) characterized by sudden wilting and death of young shoots, entire canes, and eventually whole bushes, developed throughout the northeastern United States with devastating consequences for the currant industry $(11,12,15)$. Although extensive investigations were carried out at the time to determine possible causes and means of managing the disease, which was eventually dubbed currant cane dieback, success was not forthcoming (30). The causal agent of the disease was initially believed to be the fungus Nectria cinnabarina (11), but subsequent analyses demonstrated that the fungus responsible for currant cane dieback was Botryosphaeria ribis Gross. \& Dug. (15), which is a relatively common pathogen causing limb and cane death in many bushberry, tree fruit, and woody vine crops $(13,28,29,34)$. Conversely, $N$. cinnabarina was determined to

Corresponding author: K. D. Cox

E-mail: kdc33@cornell.edu

Accepted for publication 14 July 2010.

doi:10.1094/PDIS-04-10-0295

(C) 2010 The American Phytopathological Society be a saprobe that is often found on currants already declining from dieback and may, in effect, be an indicator of Botryosphaeria infection (15).

Interestingly, this epidemic occurred at a time when white pine blister rust (WPBR), caused by the fungus Cronartium ribicola, was greatly impacting the white pine industry in the United States $(12,15,19,30)$. Like other macrocyclic rust diseases, the WPBR fungus requires two hosts to complete its life cycle: one of several pine species (Pinus spp.) and species of Ribes $(19,20)$. In an effort to eliminate this disease, Ribes quarantine and eradication legislation, as well as bans on currant production, were put into effect in 1917 (19). These federal sanctions were removed in the 1960s due to the development of rust resistant pines, and were subsequently implemented on a state-to-state basis $(3,19)$. After these planting constraints were eased in New York in 2003, Ribes spp. exhibiting symptoms of currant cane dieback were reported near Ithaca, NY (26). In 2006 alone, eight producers of currants in the Finger Lakes and Hudson Valley regions of New York, as well as in Connecticut, related concerns to the extension program of the corresponding author regarding currant decline and resultant economic losses at their operations.
With widespread planting of blister rust resistant currant cultivars, the ability to manage currant diseases other than white pine blister rust will be of utmost importance for currant production operations in the coming years. In this study, we observed and confirmed reemergence of currant cane dieback in the northeastern United States, and verified that $N$. ribis was the cause of the disease using morphological and ribosomal DNA (rDNA) sequence analyses. In addition, we conducted field trials in 2007 and 2008 to evaluate the effects of management practices on the development of cane dieback, the preliminary results of which have been presented (7). Since currant cane dieback has recently reemerged and management practices have yet to be validated for this disease in current production systems, our goal was to investigate the potential value of pruning in the form of removing symptomatic shoots, as well as the application of copper and sulfur fungicides, for management of this disease. Specifically, we endeavored to: (i) determine potential differences in dieback susceptibility among two red fruiting cultivars, one pink fruiting cultivar, and one white fruiting cultivar widely grown in the northeastern United States; (ii) evaluate the effect of pruning symptomatic shoots on disease development; and (iii) ascertain whether "delayed dormant" applications of copper and sulfur fungicides (i.e., applied between bud swell and bud break) would significantly reduce disease development.

\section{MATERIALS AND METHODS}

Ribes samples and fungal isolations. In 2006, currant cane samples were collected from four commercial currant production sites (Germantown, Staatsburg, and Highland, NY, and Preston, CT) selected on the basis of currant acreage and the presence of currant cane dieback symptoms. Ribes plantings in Germantown consisted primarily of a red fruiting currant cultivar ( $R$. rubrum cv. Rovada), while those at the remaining sites were planted primarily with a black fruiting currant cultivar ( $R$. nigrum cv. Titania). At each location, 30 symptomatic canes from 10 bushes (3 canes/bush) were collected, and three 5-mm-thick cane sections (discs) were cut from the advancing margin of 
infection in the cortex of each symptomatic cane. Each cane section was surfacesterilized by submerging the section in $10 \%$ bleach $(0.6 \% \mathrm{NaOCl})$ for 2 min while manually agitating the section. Subsequently, each cane section was washed twice with sterile distilled water for 1 $\mathrm{min} /$ wash, and then placed on potato dextrose agar (PDA; Difco Laboratories, Sparks, MD) amended with $50 \mu \mathrm{g} / \mathrm{ml}$ streptomycin sulfate (Sigma Aldrich, St. Louis, MO) to prevent bacterial growth. Fungal cultures that developed on the plates were incubated in the dark at room temperature $\left(24\right.$ to $26^{\circ} \mathrm{C}$ ) for 1 to 2 weeks. Colonies growing from the sections were subcultured and maintained on PDA in the dark at room temperature $\left(24\right.$ to $\left.26^{\circ} \mathrm{C}\right)$ for subsequent molecular and colony morphology-based identification. To view the spores, fungal stromata containing pycnidia were excised from the same set of infected canes used for isolation. Excised pycnidia were taken from the distal ends of the canes as stromata were not observed at the margin of pathogen invasion of cortex tissue. Excised stromata were sectioned in a drop of water on a microscope slide using a carbon steel surgical blade (no. 11) to release conidia for viewing with an Olympus BX50 light microscope (Olympus America, Center Valley, PA) attached to a SPOT Idea digital camera (Diagnostic Instruments, Sterling Heights, MI). Morphological examination of colonies from the PDA plates, as well as conidia from excised stromata and those produced in culture, was used with a taxonomic key (2) and published fungal descriptions $(9,21$, $23,25,34)$ to identify the isolated fungal species.

Molecular characterization of $\mathrm{N}$. ribis. Genomic DNA was extracted from 2week-old putative cultures of $N$. ribis using the UltraClean Soil DNA Isolation Kit (MO BIO Laboratories, Carlsbad, CA). Extractions were carried out using three representative putative $N$. ribis isolates from each of the four field sites. Approximately $100 \mathrm{ng}$ of template DNA was utilized to amplify a 492-bp region, including the internal transcribed spacer (ITS) regions of the nuclear ribosomal repeat unit with primers ITS1-F (14) and ITS4 (33), using Taq DNA polymerase (Promega, Madison, WI) according to the manufacturer's instructions. Reactions containing no template DNA were included as a negative control. Cycling parameters for ITS amplification were as follows: one cycle of $94^{\circ} \mathrm{C}$ for $2 \mathrm{~min}$; followed by 30 cycles of $94^{\circ} \mathrm{C}$ for $30 \mathrm{~s}, 55^{\circ} \mathrm{C}$ for $30 \mathrm{~s}$, and $72^{\circ} \mathrm{C}$ for $30 \mathrm{~s}$; with a final extension of $72^{\circ} \mathrm{C}$ for 10 min. Reactions were performed in an $\mathrm{iCy}-$ cler thermal cycler (BioRad Laboratories, Hercules, CA). PCR products were visualized on $2 \%$ agarose gels stained with ethidium bromide under UV illumination.

DNA amplicons were purified using the QIAquick PCR purification kit (QIAGEN,
Valencia, CA) and were subsequently sequenced using Big Dye Terminator chemistry (Applied Biosystems, Foster City, CA) and AmpliTaq-FS DNA Polymerase (Applied Biosystems) using the Applied Biosystems Automated 3730xl DNA Analyzer at the Cornell University DNA Sequencing facility in Ithaca, NY. All nucleotide sequences were aligned using CLUSTAL W (31) and compared to previously reported sequences using BLAST (1).

To verify pathogenicity on currants of the $N$. ribis isolates obtained from cane dieback affected plantings in 2006, an inoculation trial was carried out in early April 2007 at the bud burst growth stage, at the New York State Agricultural Experiment Station in Geneva. The experimental site consisted of a 7-year-old mixed planting of red fruiting currants (R. rubrum cv. Red Lake), black fruiting currants $(R$. nigrum cv. Ben Alder), and gooseberry ( $R$. grossularia cv. Achilles) with no history of currant cane dieback. The planting comprised five rows each with 15 three-bush plots containing one bush of each of the three aforementioned Ribes species.

To generate $N$. ribis spore inoculum, one of the fungal isolates (TMSF 3A) obtained from Germantown was grown on 20 plates of $2 \%$ water agar amended with sterilized eastern white pine (Pinus strobus) needles and incubated in the dark at room temperature $\left(24\right.$ to $\left.26^{\circ} \mathrm{C}\right)$ to induce conidial production. After approximately 14 to 21 days, pine needles with visible pycnidia were excised using a carbon steel surgical blade (no. 11) and vortexed (Vortex Genie 2, Scientific Industries, Bohemia, NY) at maximum speed in $1 \mathrm{ml}$ of sterile distilled water for $1 \mathrm{~min}$. The resulting conidial suspensions were each adjusted to approximately $10^{5}$ conidia/ml.

Inoculations were performed by selecting the five most terminal open buds (showing green tissue) from each of three shoots from each of 15 healthy Red Lake and Ben Alder bushes. Each bud was inoculated with $250 \mu \mathrm{l}$ of the spore suspension or with sterile distilled water for the control plants. The number of symptomatic (see results for a description of disease symptoms) inoculated and noninoculated terminal shoots per bush was assessed at harvest the same year. Fungal isolations were subsequently made from 10 noninoculated, asymptomatic shoots and 10 inoculated, symptomatic shoots (one shoot harvested/bush), and the isolates were identified using spore and colony morphology as described above.

Field trials. A field trial was set up in each of 2007 and 2008 to evaluate the effects of currant cultivar, fungicides, and pruning on the development of cane dieback symptoms. The trial site in Germantown consisted of mature plantings of 6year-old red (Rovada and Jonkheer van Tets), pink (Pink Champagne), and white (Blanka) fruiting currants of similar vigor.
The site had a naturally high incidence of currant cane dieback observed in 2006, and was within the same region in which several investigations into this disease were made 80 to 100 years ago $(11,12,15)$. The planting consisted of six alternating cultivar blocks each with six rows of each of four cultivars (Rovada, Jonkheer van Tets, Pink Champagne, and Blanka). Additional plantings of Rovada, gooseberries, brambles, and cherries were located nearby. The field trial was set up as a splitsplit-plot design with cultivar as the main plot factor, fungicide treatment as the splitplot factor, and pruning treatment as the split-split-plot factor. Within each cultivar block (main plot), the six rows were divided into split-plots of two rows randomly selected for each of three fungicide treatments (see below). Each set of two rows within each split-plot was randomly designated as a split-split plot for the two pruning treatments (see below). Each splitsplit-plot consisted of 10 bushes assessed for the development of cane blight symptoms. Each main plot, corresponding splitplots, and split-split plots was replicated three times using additional six-row cultivar blocks at the trial site. A minimum of 20 bushes served as a buffer between main plots.

The experiment was conducted in 2007 and repeated in 2008 using different portions of the planting to avoid confounding treatment effects between the two seasons. In 2007, the first three alternating cultivar blocks were used for the experiment, and in 2008 the split-plots and split-split-plots were rerandomized in the remaining three alternating cultivar blocks. Prior to the experiments, all dead canes were removed from the currant bushes at the experimental field site (in September of each of 2006 and 2007) so that only newly killed canes were assessed during each trial.

Fungicide programs. We chose to evaluate "delayed dormant" applications of copper and sulfur fungicides because such applications are common disease management practices in small fruit production systems (6). Since copper and sulfur fungicides are widely labeled in the United States for disease management on currants, delayed dormant copper and sulfur fungicide programs can readily be adopted by U.S. currant growers. Copper, sulfur, and control (no fungicide) treatments were applied to split-plots. Copper hydroxide (Kocide DF: $40 \%$ metallic copper equivalent, Kocide DF, Griffin LLC, Valdosta, GA) and sulfur (Kumulus DF, Micro Flo Company LLC, Arysta LifeScience, Memphis, TN) were applied at $11.2 \mathrm{~kg} / \mathrm{ha}$ and $6.72 \mathrm{~kg} / \mathrm{ha}$, respectively. Fungicide applications were made at $50 \%$ bud break (i.e., when at least $50 \%$ of the dormant buds had broken) and approximately 14 days later at $100 \%$ green tip (i.e., when all leaf buds displayed approximately $0.6 \mathrm{~cm}$ of green tissue) each year (6). Applications were 
conducted using a small, tractor-pulled, 114 liter, vertical boom sprayer equipped with three TP8004E nozzles (TeeJet, Wheaton, IL) per boom at a $25.4-\mathrm{cm}$ nozzle spacing with an operating pressure of $0.3 \mathrm{kPa}$ and driving speed of $4.82 \mathrm{~km} / \mathrm{h}$. All split-plot control plots were sprayed with water at the same application timings as the fungicides.

Pruning treatments. Plants within each split-split-plot were either pruned or not pruned. While fall pruning was used to remove dead canes or canes exhibiting obvious disease symptoms prior to the trial, canes with quiescent infections that failed to overwinter were evident as dead canes the next spring. Pruning consisted of removing declining canes, dead canes, or canes on which fungal stromata were observed in the spring of each season, immediately prior to applying the fungicide treatments. Canes were pruned to the crown and removed from the trial site. In the control (nonpruned) plots, infected canes were left intact and flagged in the spring so they were not included in cane dieback assessments at harvest. Hence, only newly infected and symptomatic canes were used for disease assessments following these treatments.

Dieback assessment and statistical analyses. At harvest of each year (18 August 2007 and 16 August 2008), the incidence of cane dieback symptoms was assessed for each bush in each split-splitplot. On each bush, the number of symptomatic terminal shoots (including those on which fungal stromata were observed) and the total number of terminal shoots per bush were counted. The incidence of cane dieback was expressed as the percentage of symptomatic shoots based on the total number of shoots evaluated. Prior to statistical analysis, the response variable (percentage of symptomatic shoots) was arcsine-square root-transformed to stabilize the variance. The effects of cultivar, pruning, and fungicide treatments were analyzed using analysis of variance (ANOVA) for a split-split-plot design by the PROC MIXED procedure of SAS (Version 9.2; SAS Institute, Cary, NC) as previously described (8). Main effects and interactions were considered statistically significant at $\alpha=0.05$. Adjusted estimated mean disease incidences are reported for specific treatments and treatment combinations using the LSMEANS procedure of SAS. Preplanned multiple comparisons were made using the CONTRAST, ESTIMATE, and LSMEANS procedures of SAS to confirm the significance of specific comparisons presented to illustrate the main effects and interactions.

\section{RESULTS}

Description of disease symptoms. Currant cane dieback symptoms were observed at commercial currant operations in Germantown (Rovada), Staatsburg, and
Highland, NY, and in Preston, CT (Titania). At each location, all plantings were similarly affected. Some bushes were more severely symptomatic than others, and were distributed randomly throughout the plantings. With the exception of the plantings in Preston, none of the affected plantings exhibited any indication of currant cane borer (Synanthedon tipuliformis), which may cause a similar cane decline (16). Canes with dieback displayed a progressive wilt of shoot tips over the summer months, which led to the death of mature canes by late summer/early fall (Fig. 1A to C). The leaves of infected canes initially became chlorotic and canes eventually died as infection progressed (Fig. 1B). The cortex and pith of newly infected shoots and canes were often discolored (light tan) (Fig. 1D). In later stages of infection, the pith was often completely necrotic (dark brown to black) (Fig. 1E) and subsequently completely decayed, leaving hollow canes that snapped off easily. Small, black, fungal stromata (Fig. 1F) containing pycnidia, which produced conidia (Fig. 1G) characteristic of $N$. ribis, were often observed on mature canes and sometimes on infected shoot tips. As previously reported (15), coral-colored stromata diagnostic of fruiting bodies of $N$. cinnabarina were also observed (Fig. 1H) on mature infected canes from the previous season, suggesting secondary colonization of the infected tissues. On such canes, stromata of $N$. ribis often were also present, but not at the same location as $N$. cinnabarina.

Presence of $\boldsymbol{N}$. ribis on diseased canes. $N$. ribis was isolated from 25 of 33 canes in Germantown, 23 of 33 canes in Staatsburg, 28 of 33 canes in Highland, and 22 of 27 canes in Preston (3 canes sampled/bush) exhibiting dieback symptoms from the commercial currant operations in 2006. Fungi isolated from the symptomatic canes displayed colony morphology (e.g., pale gray colonies with indeterminate margins composed of soft, fluffy mycelium with sparse tufts of pale white, aerial mycelia) typical of Botryosphaeria spp. and produced hyaline, fusiform, aseptate conidia (Fig. 1G) 10 to $13 \mu \mathrm{m}$ in length that were characteristic of $N$. ribis $(21,23,25,34)$. Four canes yielded $N$. cinnabarina, two yielded Fusarium spp., and 22 yielded unidentified yeasts (data not shown).

Sequencing of a 492-bp amplicon spanning the ITS regions and $5.8 \mathrm{~S}$ gene in the nuclear rDNA, from each of three representative $N$. ribis isolates from all four commercial operations, indicated $100 \%$ nucleotide identity with a previously published B. ribis sequence (GenBank accession no. AF027743). The DNA sequences were also identical to that of a closely related fungus, Neofusicoccum parvum (GenBank accession no. FJ790827). However, the lack of septate conidia each bearing a pigmented middle cell from 2-week- old cultures, which are characteristic of the latter species (26), indicated that the isolated fungi were $N$. ribis. Although the fungi were identified using colony characteristics and rDNA sequence of the teleomorph, B. ribis, conidia were produced by the anamorph, $N$. ribis (9). Hence, we refer to the pathogen as the anamorph throughout the text, since the teleomorph was not observed in the field.

Confirmation of $N$. ribis as the cause of cane dieback. At harvest of the currant planting containing the pathogenicity trial, no symptomatic shoot tips were observed in either the water-inoculated control bushes or the N. ribis-inoculated Ben Alder bushes. Conversely, all but one Red Lake bush inoculated with the spore suspension developed at least one symptomatic shoot tip, and 7 of the $15 \mathrm{~N}$. ribisinoculated bushes exhibited decline of all three inoculated shoot tips. Furthermore, fungi subsequently isolated from 10 diseased Red Lake canes all displayed mycelial and conidial morphology characteristic of $N$. ribis. $N$. ribis was never isolated from any canes on asymptomatic or waterinoculated bushes in this study.

Effects of currant cultivar, fungicide treatment, and pruning on cane dieback. Currant cane dieback symptoms and $N$. ribis stromata were observed on all four currant cultivars in all of the plots in Germantown. In both 2007 and 2008, the mean incidence of cane dieback ranged from 0 to $60.0 \%$ across all four cultivars and all six treatment combinations. In both 2007 and 2008, the main effects of cultivar, pruning, and fungicide treatment significantly influenced the incidence of dieback $(P<0.05)$. There were also significant interactions between cultivar and fungicide treatments in $2007(P=$ $0.0001)$ and $2008(P=0.0123)$, and pruning and fungicide treatments in $2007(P<$ $0.0001)$ and $2008(P=0.0144)$. The interactions between cultivar and pruning were not significant in either 2007 or $2008(P>$ $0.05)$. Due to the significant interactions, estimated adjusted means of main effects, as determined by the LSMEANS procedure of SAS, are presented separately for each cultivar and fungicide treatment combination (Fig. 2).

Bushes of the cultivar Pink Champagne that did not receive fungicide applications or pruning had a significantly lower incidence of dieback $(22.0 \%)$ than all other cultivars in 2007 and 2008 (Fig. 2). There were slight, but significant, differences in the incidence of cane dieback among cultivars Blanka, Jonkheer van Tets, and Rovada in 2007, but none of these differences was consistent over both years (Fig. 2).

Fungicide treatments significantly affected the incidence of dieback, but the magnitude of the effect was influenced by cultivar as evidenced by the significant interaction between cultivar and fungicide treatments in both years. For example, in 

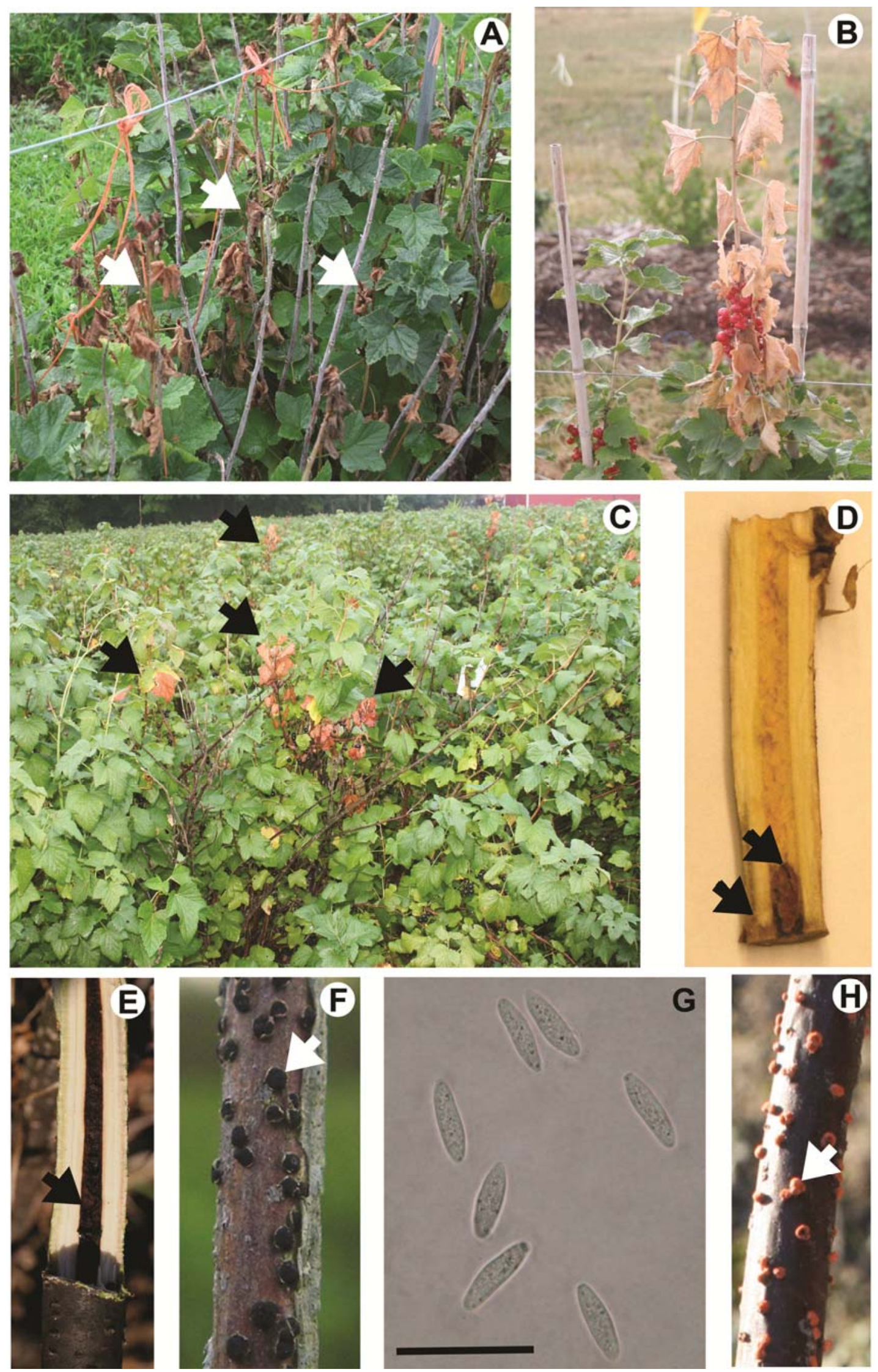

Fig. 1. Characteristics of symptomatic currants resulting from infection by the fungal pathogen Neofusicoccum ribis. A, Cultivar Titania black fruiting currants from Preston, CT, exhibiting symptoms of currant cane dieback in late spring/early summer with dead and dying shoots (arrows). B, Inoculated red fruiting currant terminal shoot exhibiting severe dieback. C, Titania black fruiting currants from Preston with dead canes (arrows) and young shoots becoming chlorotic. D, Discoloration and necrosis (arrows) in the advancing margin of an active dieback canker within an infected cane. E, Pith necrosis (arrow) down the length of a currant cane resulting from primary and secondary infection of dead tissue. F, N. ribis stromata (arrow) on a dead Titania black fruiting currant cane in Preston. G, Fusiform, hyaline, aseptate conidia of N. ribis. Scale bar $=25 \mu \mathrm{m}$. H, Coral-colored stromata of Nectria cinnabarina (arrow) on a dead currant cane historically reported as a secondary colonizer of cane dieback-infected shoots in the northeastern United States. 
2007 the incidence of dieback on Rovada and Pink Champagne bushes treated with copper that had not been pruned (64.4 and $27.0 \%$, respectively) was significantly higher than that of bushes that received neither fungicide treatment nor pruning (55.0 and $22.0 \%$, respectively) (Fig. 2E and $\mathrm{G})$. By comparison, Jonkheer van Tets bushes treated with copper but not pruned had a significantly lower dieback incidence (36.0\%) than bushes that received neither fungicide treatment nor pruning $(48.0 \%)$ (Fig. 2C). The effect of fungicide treatment on dieback incidence was also influenced by pruning as evidenced by the significant interaction between fungicide treatment and pruning treatment in 2007 ( $P$ $<0.0001)$ and $2008(P=0.0144)$. For all cultivars in both years, the incidence of dieback was more statistically similar among fungicide-treated bushes that were not pruned compared to bushes that were pruned (Fig. 2). For example, the incidence of dieback on pruned bushes treated with copper hydroxide or sulfur was significantly lower than that of nonpruned bushes treated with copper hydroxide or sulfur (Fig. 2). Similarly, with the exception of Rovada, the incidence of dieback on pruned bushes treated with copper hydroxide and sulfur was consistently lower than on pruned bushes that did not receive fungicide treatments (Fig. 2). For Rovada, pruned bushes had significantly lower incidence than those not pruned regardless of fungicide treatment in 2007, but in 2008 , only the pruned bushes treated with copper hydroxide or sulfur had significantly less dieback than bushes from corresponding treatments that were not pruned.

\section{DISCUSSION}

After nearly a century without any record of currant cane dieback in the northeastern United States, there has been a reemergence of the disease in this region (26). This almost certainly resulted from relaxation in many states of bans on Ribes production that were initiated in the early 1900 s to control WPBR. The signs and symptoms of these recent outbreaks of currant cane dieback were consistent with initial reports from the late nineteenth and early twentieth centuries describing the disease $(11,12,15)$, with sudden wilt and death of currant canes from spring to late summer/early fall, as well as eventual necrosis of the pith and development of small, black fungal stromata on infected shoots.

More than $69 \%$ of fungal isolates obtained from tissues sampled at the margin of dieback cankers on currant bushes in Germantown, Staatsburg, and Highland, NY, as well as Preston, CT, exhibited morphological and molecular traits characteristic of the pathogen B. ribis (syn. N. ribis), which was identified as the causal pathogen of currant cane dieback in the early twentieth century (15). In addition, we confirmed pathogenicity of this fungus by inoculating young buds of healthy bushes of the $R$. rubrum cv. Red Lake with conidial suspensions of $N$. ribis, observing symptoms typical of this currant cane dieback on the inoculated bushes, and subsequently reisolating the fungus from diseased canes.

Because little progress was made in developing management strategies for the disease during the epidemics described nearly a century ago (30), we sought to reinvestigate the potential for pruning combined with applications of copper and sulfur fungicides for management of this disease on red (Rovada and Jonkheer van Tets), pink (Pink Champagne), and white (Blanka) fruiting currant cultivars. On bushes that were not treated with fungicides, Pink Champagne had a lower incidence of dieback than the other three cultivars in 2007 and 2008. These results indicate that, of the cultivars tested, Pink Champagne may be the least susceptible to $N$. ribis. Although this could reflect inherent resistance of pink fruiting currant cultivars to this pathogen, it is not possible to

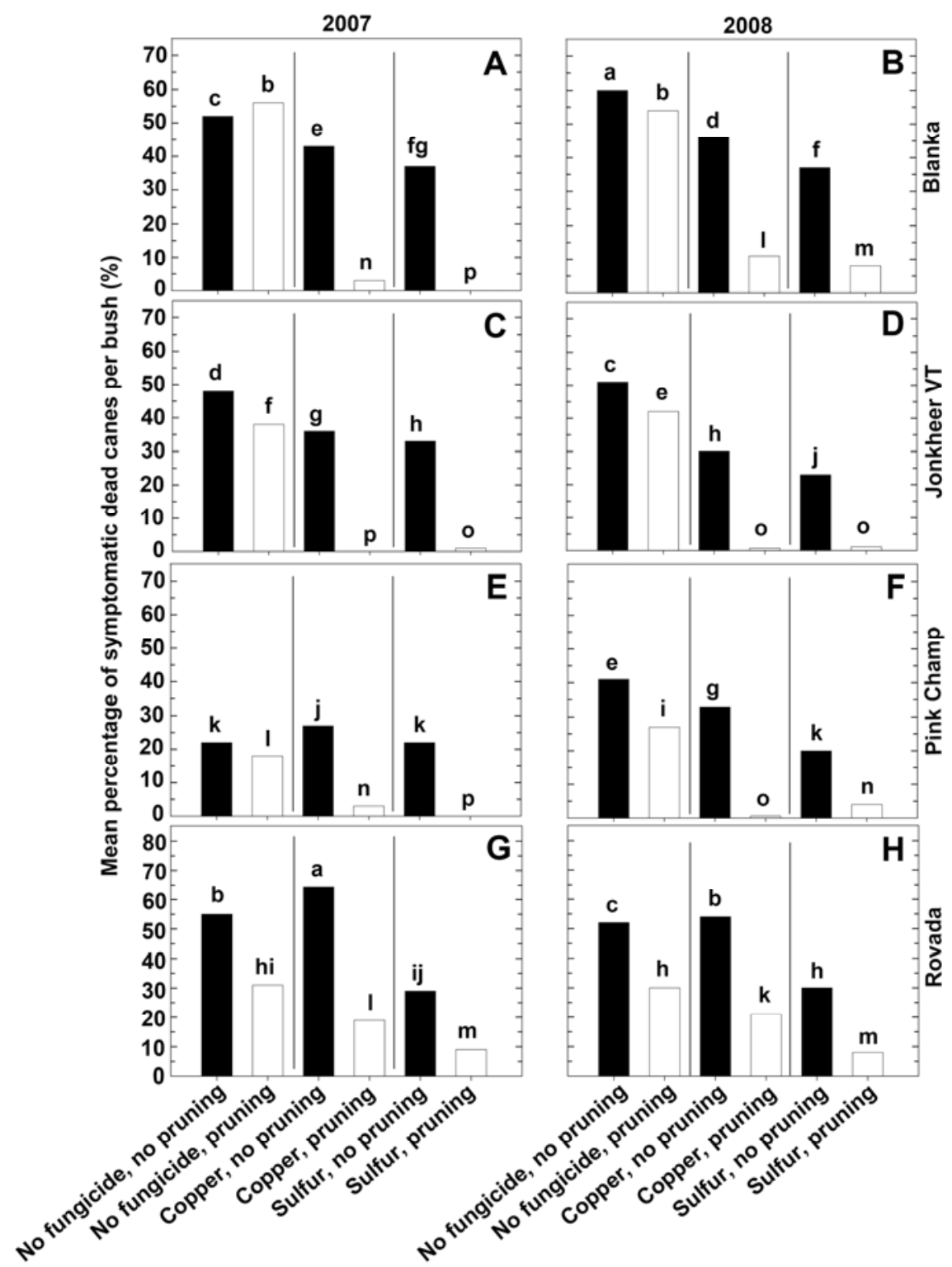

Fig. 2. Incidence of currant cane dieback infections caused by Neofusicoccum ribis for different fungicide treatments and pruning vs. no pruning evaluated on four currant cultivars in Germantown, NY, in 2007 and 2008. Cane dieback incidence in 2007 (A, C, E, and G) and 2008 (B, D, F, and H) is depicted for the cultivars Blanka (A and B), Jonkheer van Tets (Jonkheer VT) (C and D), Pink Champagne (Pink Champ) (E and $\mathrm{F})$, and Rovada $(\mathrm{G}$ and $\mathrm{H}$ ) for the main effects as determined by analysis of variance for a split-split-plot experimental design. Fungicide and pruning treatment combinations included plots in which plants were not treated with fungicides and not pruned, pruned but not treated with fungicides, pruned or nonpruned plants were treated with copper hydroxide, and pruned or nonpruned plants were treated with sulfur. Each bar represents the adjusted estimated mean incidence determined using the LSMEANS procedure of SAS (SAS Institute, Cary, NC). Bars denoted by the same letter indicate a lack of statistical significance $(\alpha=0.05)$ among adjusted estimated mean incidences for all treatment combinations in 2007 and 2008. 
assess this based on the very limited number of cultivars evaluated in this study for the different currant fruiting colors. In the inoculation studies, the red cultivar Red Lake developed the disease after being inoculated with $N$. ribis conidial suspensions, but the black cultivar Ben Alder did not become symptomatic. By contrast, the black fruiting cultivar Titania evaluated at other locations in the study had an incidence of cane dieback comparable with Rovada and Jonkheer van Tets in Germantown, NY (data not shown). Cultivar differences in susceptibility to dieback induced by other Botryosphaeria spp. have been reported in diverse plant species $(22,27)$; however, the mechanisms underlying this phenomenon remain to be evaluated.

Pruning in the form of removing blighted twigs can reduce the impact of Botryosphaeria infections on various hosts (17). Indeed, pruning out infected shoots may remove mycelia, pycnidia, or perithecia (latter were not observed in this study) embedded in diseased canes, which may serve as a source of overwintering Botryosphaeria inoculum that could initiate new infections the following year. In the absence of fungicide treatments, the effect of pruning on the incidence of currant cane dieback was inconsistent between years and among cultivars, which partially confirmed a previous report that summer pruning alone was of no benefit in the management of currant cane dieback (30). Interestingly, we found that applications of copper hydroxide and sulfur fungicides in combination with pruning resulted in the lowest incidence of cane dieback on all four cultivars. Pruned bushes receiving fungicide applications had a lower incidence of dieback compared to nonpruned bushes that had not received a fungicide application. Similarly, pruned bushes receiving fungicide applications had a lower incidence of dieback than bushes treated with the fungicides alone. Fungicide applications to pruned bushes had less of an impact on the incidence of dieback for Rovada than for Blanka, Pink Champagne, and Jonkheer van Tets. These results imply that currant cultivars may not only affect susceptibility to the disease, but may also influence the potential value of copper or sulfur fungicide applications for management of this disease.

For nearly a century, there appear to have been no reports in the United States concerning chemical management of currant cane dieback. The fungus is protected from fungicides by the woody canes in which it resides, so the utility of chemical management postinfection is expected to be limited. Fungicide treatments in this study were timed to protect susceptible cane tissues potentially wounded during spring freezes from infection by the pathogen, which may explain why the fungicide treatments significantly reduced the inci- dence of infection. There have been previous reports on the effectiveness of sitespecific fungicides against Botryosphaeria spp. in vitro $(4,24)$, as well as reports on management of Botryosphaeria diseases in the field using site-specific fungicides such as tebuconazole, benomyl, thiophanatemethyl, azoxystrobin, prochloraz mc, and mancozeb $(5,10,17,18,32)$. Unlike copper and sulfur fungicides, which are usually restricted to dormant or delayed dormant uses due to potential phytotoxicity, the site-specific fungicides are often registered for season-long use (6). Such site-specific fungicides are being utilized in other Botryosphaeria pathosystems for protective rather than curative activities, since applications have only been demonstrated to prevent symptom development, not alleviate symptoms from existing infections $(5,10)$. Dying shoots were never observed to recover from the disease in this study, as the copper hydroxide and sulfur treatments only served to prevent infections.

In summary, $N$. ribis is causing epidemics of currant cane dieback in the northeastern United States more than a century after the disease was first observed in this region. Moreover, the disease has been observed at all of the major currant production operations ( $>5$ acres) in this region. Although attempts to manage the disease in the early twentieth century were not successful (30), the availability of copper and sulfur fungicide products, and the introduction of new Ribes cultivars, should make control of currant cane dieback feasible. The results of this study suggest that by combining pruning with chemical applications of protectant fungicides, the disease can be managed effectively.

\section{ACKNOWLEDGMENTS}

This study was supported by funding from the New York Berry Growers Association in addition to state, federal, and institutional funds appropriated to the New York State Agricultural Experiment Station, Cornell University. This study is part of CSREES project NYG-625420 (Accession: 021118). We also thank Peter Ojiambo for his assistance with the description and the validation of statistical analysis procedures used in the manuscript.

\section{LITERATURE CITED}

1. Altschul, S. F., Gish, W., Miller, W., Myers, E. W., and Lipman, D. J. 1990. Basic local alignment search tool. J. Mol. Biol. 215:403410 .

2. Barnett, H. L., and Hunter, B. B. 1998. Illustrated Genera of Imperfect Fungi, 4th ed. American Phytopathological Society, St. Paul, MN.

3. Barney, D. L. 2000. Commercial production of currants and gooseberries in the inland northwest and intermountain west of the United States: Opportunities and risks. Hortic. Technol. 10:557-561.

4. Bester, W., Crous, P. W., and Fourie, P. H. 2007. Evaluation of fungicides as potential grapevine pruning wound protectants against Botryosphaeria species. Australas. Plant Pathol. 36:73-77.

5. Brown-Rytlewski, D. E., and McManus, P. S. 2000. Virulence of Botryosphaeria dothidea and Botryosphaeria obtusa on apple and man- agement of stem cankers with fungicides. Plant Dis. 84:1031-1037.

6. Cox, K. D., and English-Loeb, G. 2010. Ribes: Insects and diseases - time for concern. Pages 85-93 in: Pest Management Guidelines for Berry Crops. M. Pritts and M. C. Heidenreich, eds. Cornell University Pesticide Management Education Program, Ithaca, NY.

7. Cox, K. D., Jamann, T., and McKay, S. A 2008. Currant cane dieback in NY: Preliminary data from the Hudson Valley trial. New York Fruit Quart. 16:11-15.

8. Cox, K. D., and Scherm, H. 2001. Oversummer survival of Monilinia vaccinii-corymbosi in relation to pseudosclerotial maturity and soil surface environment. Plant Dis. 85:723-730.

9. Crous, P. W., Slippers, B., Wingfield, M. J., Rheeder, J., Marasas, F. O., Philips, A. J. L. Alves, A., Burgess, T., Barber, P., and Groenwald, J. Z. 2006. Phylogenetic lineages in the Botryosphaeriaceae. Stud. Mycol. 55:235-253.

10. Denman, S., Crous, P. W., Sadie, A., and Wingfield, M. J. 2004. Evaluation of fungicides for the control of Botryosphaeria protearum on Protea magnifica in the Western Cape Province of South Africa. Australas. Plant Pathol. 33:97-102.

11. Durand, E. J. 1897. A disease of currant canes. New York State Agric. Exp. Stn. Geneva Bull. 125:23-38

12. Fairchild, D. G. 1891. Notes on a new and destructive disease of currant canes. Bot. Gaz. 16:262.

13. Fenner, E. A. 1925. A rot of apples caused by Botryosphaeria ribis. Phytopathology 15:230234.

14. Gardes, M., and Bruns, T. D. 1993. ITS primers with enhanced specificity for basidiomycetes: Application to the identification of mycorrhizae and rusts. Mol. Ecol. 2:113-118.

15. Grossenbacher, J. G., and Duggar, B. M. 1911. A contribution to the life-history, parasitism, and biology of Botryosphaeria ribis. New York State Agric. Exp. Stn. Geneva Tech. Bull. 18:113-190

16. Hardy R. J. 1981. Field observations on the effect of currant borer moth Synanthedon tipuliformis (Clerck) (Lepidoptera: Aegeriidae) on the yield of blackcurrants produced in Tasmania. Sci. Hortic. 15:165-172.

17. Holtz, B., Sibbett, S., Kallsen, C., Hendricks, L., Beede, B., Michailides, T., Teviotdale, B., and Ferguson, L. 2002. Evaluation of pruning and fungicide sprays to control Botryosphaeria blight of Pistacia vera. Acta Hortic. 591:569575 .

18. Li, H.-Y., Cao, R.-B., and Mu, Y.-T. 1995. In vitro inhibition of Botryosphaeria dothidea and Lasiodiplodia theobromae, and chemical control of gummosis disease of Japanese apricot and peach trees in Zhejiang Province, China. Crop Prot. 14:187-191.

19. Maloy, O. C. 1997. White pine blister rust control in North America: A case history. Annu. Rev. Phytopathol. 35:87-109.

20. McKay, S. 2000. State regulation of Ribes to control white pine blister rust. Hortic. Technol. 10:562-564.

21. Punithalingam, E., and Holliday, P. 1973 Botryosphaeria ribis. Description of Pathogenic Fungi and Bacteria, No. 395. Commonw. Mycol. Inst. Assoc. Appl. Biol., Kew, Surrey, England.

22. Ramos, L. J., Davenport, T. L., McMillan, R. T., Jr., and Lara, S. P. 1997. The resistance of mango (Mangifera indica) cultivars to tip dieback disease in Florida. Plant Dis. 81:509-514.

23. Rayachhetry, M. B., Webb, R. S., and Kimbrough, J. W. 1996. Characteristics of the Fusicoccum anamorph of Botryosphaeria ribis, a potential biological control agent for Melaleuca quinquenervia in South Florida. Mycologia 88:239-248.

24. Savocchia, S., Laurent, E. N., Stodart, B. J., 
and Steel, C. C. 2005. Botryosphaeria canker and sensitivity to fungicides in vitro. Page 88 in: Proc. 43rd Annu. Congr. South Afr. Soc. Plant Pathol., Mossel Bay, South Africa.

25. Schnabel, G., Chai, W., and Cox, K. D. 2006. Identification and management of a summer disease complex on 'Babygold' peach. Plant Health Progress doi:10.1094/PHP-2006-030101-RS.

26. Slippers, B., Crous, P. W., and Denman, S. 2004. Combined multiple gene genealogies and phenotypic characteristics differentiate several species previously identified as Botryosphaeria dothidea. Mycologia 96:83-101.

27. Smith, B. J. 2009. Botryosphaeria stem blight of southern blueberries: Cultivar susceptibility and effect of chemical treatments. Acta Hortic. 810:385-394

28. Smith, C. O. 1934. Inoculations showing the wide host range of Botryosphaeria ribis. J. Agric. Res. 49:467-476.

29. Stevens, N. E., and Jenkins, A. F. 1924. Occurrence of the currant cane blight fungus on other hosts. J. Agric. Res. 27:837-844.

30. Stewart, F. C. 1913. An experiment on the control of currant cane necrosis by summer pruning. New York State Agric. Exp. Stn. Geneva Bull. 357:113-190.

31. Thompson, J. D., Higgins, D. J., and Gibson, T. J. 1994. CLUSTAL W: Improving the sensitivity of progressive multiple sequence alignment through sequence weighting, position- specific gap penalties and weight matrix choice. Nucleic Acids Res. 22:4673-4680.

32. Tuset, J. J., Hinarejos, C., and Portilla, M. T. 1997. Incidence of Phomopsis amygdali, Bot ryosphaeria berengeriana and Valsa cincta diseases in almond under different control strategies. OEPP/EPPO Bull. 27:449-454.

33. White, T. J., Bruns, T., Lee, S., and Taylor, J. 1990. Amplification and direct sequencing of fungal and ribosomal RNA genes for phylogenetics. Pages 315-322 in: PCR Protocols: A Guide to Methods and Applications. Academic Press, San Diego, CA

34. Wolf, F. T., and Wolf, F. A. 1939. A study of Botryosphaeria ribis on willow. Mycologia 31:217-227. 